\title{
Intersectorality and Bonding in Tuberculosis Control in Family Health
}

\author{
Lenilde Duarte de Sá1 \\ Anna Luiza Castro Gomes ${ }^{2}$ \\ Jordana de Almeida Nogueira ${ }^{3}$ \\ Tereza Cristina Scatena Villa ${ }^{4}$ \\ Káren Mendes Jorge de Souza ${ }^{5}$ \\ Pedro Fredemir Palha ${ }^{6}$
}

This is a qualitative study which aims to analyze the performance of the Family Health teams in the control of tuberculosis according to the relationship between bonding and the development of intersectoral actions in the metropolitan region of João Pessoa, Paraíba, Brazil. To construct the empirical material focus group techniques were used. Seven focus groups were conducted, involving 37 professionals of the Family Health teams. For analysis, the discourse analysis technique was used. It was concluded that the lack of intersectoral action weakens the bond between tuberculosis patients, their families and the Family Health team. It is noteworthy that intersectoral measures are fundamental in the development of integral care for tuberculosis patients in the context of Primary Health Care.

Descriptors: Tuberculosis; Family Health Program; Primary Health Care.

\footnotetext{
${ }^{1}$ RN, Ph.D. in Nursing, Associate Professor, Universidade Federal da Paraíba, João Pessoa, PB, Brazil. E-mail: lenilde_sa@yahoo.com.br.

${ }^{2}$ RN, Doctoral Student in Public Health, Fundação Oswaldo Cruz (FIOCRUZ), Rio de Janeiro, RJ, Brazil. Associate Professor, Universidade Federal da Paraíba, PB, Brazil. E-mail: annaenf@gmail.com.br.

${ }^{3}$ RN, Ph.D. in Nursing, Adjunct Professor, Universidade Federal da Paraíba, João Pessoa, PB, Brazil E-mail: jal_nogueira@yahoo.com.br.

${ }^{4}$ RN, Ph.D. in Nursing, Full Professor, Escola de Enfermagem de Ribeirão Preto, Universidade de São Paulo, WHO Collaborating Centre for Nursing Research Development, SP, Brazil. E-mail: tite@eerp.usp.br.

${ }^{5}$ Doctoral student in Nursing, Escola de Enfermagem de Ribeirão Preto, Universidade de São Paulo, WHO Collaborating Centre for Nursing Research Development, SP, Brazil. E-mail: karensouza@usp.br.

${ }^{6}$ RN, Ph.D. in Nursing, Associate Professor, Escola de Enfermagem de Ribeirão Preto, Universidade de São Paulo, WHO Collaborating Centre for Nursing Research Development, SP, Brazil. E-mail: palha@eerp.usp.br.
}

\author{
Corresponding Author: \\ Lenilde Duarte de Sá \\ Universidade Federal da Paraíba. Centro de Ciências da Saúde \\ Programa de Pós-Graduação em Enfermagem \\ Campus Universitário I \\ CEP: 58050-900 João Pessoa, PB, Brasil \\ E-mail: lenilde_sa@yahoo.com.br
}




\title{
Intersetorialidade e vínculo no controle da tuberculose na Saúde da Família
}

Trata-se de estudo de abordagem qualitativa, cujo objetivo foi analisar o desempenho das equipes de Saúde da Família no controle da tuberculose, segundo a relação entre vínculo e o desenvolvimento de ações intersetoriais, em município da região metropolitana de João Pessoa, Paraíba, Brasil. Para a construção do material empírico, foi utilizada a técnica de grupo focal. Sete grupos focais foram realizados, envolvendo 37 profissionais das equipes de Saúde da Família. Para análise, utilizou-se a técnica de análise do discurso. Conclui-se que a escassez de ações intersetoriais fragiliza o vínculo entre o doente de tuberculose, sua família e a equipe de Saúde da Família. Destaca-se que medidas intersetoriais são fundamentais para o desenvolvimento de cuidado integral ao doente de tuberculose, no âmbito da Atenção Primária à Saúde.

Descritores: Tuberculose; Programa Saúde da Família; Atenção Primária à Saúde.

\section{Acciones intersectoriales y vínculo en el control de la tuberculosis en la Salud de la Familia}

\begin{abstract}
Se trata de un estudio de abordaje cualitativo, cuyo objetivo fue analizar el desempeño de los equipos de Salud de la Familia en el control de la tuberculosis según la relación entre vínculo y desarrollo de acciones intersectoriales en un municipio de la región metropolitana de Joao Pesoa, en el estado de Paraíba, en Brasil. Para la construcción del material empírico fue utilizada la técnica de grupo focal. Siete grupos focales fueron realizados, envolviendo 37 profesionales de los equipos de Salud de la Familia. Para el análisis, se utilizó la técnica de análisis del discurso. Se concluye que la escasez de acciones intersectoriales fragiliza el vínculo entre el enfermo de tuberculosis, su familia y el equipo de Salud de la Familia. Se destaca que las medidas intersectoriales son fundamentales para el desarrollo de un cuidado integral al enfermo de tuberculosis en el ámbito de la Atención Básica a la Salud.
\end{abstract}

Descriptores: Tuberculosis; Programa de Salud Familiar; Atención Primaria de Salud.

\section{Introduction}

Tuberculosis (TB) is considered one of the serious public health problems that affect the population, being distributed throughout the five continents of the globe. The fact that there is treatment and a cure has not stopped a significant growth of the indicators of morbiditymortality, which represents a major challenge for the health authorities in Brazil and worldwide. Although policies and strategies to control the disease have been developed, impoverishment, urbanization, slums, heavy migration and the pandemic of infection with Human Immunodeficiency Virus (HIV) have impaired worldwide the fight against $\mathrm{TB}^{(1)}$.
The World Health Organization (WHO) estimates that, in 2008, 9.4 million new TB cases occurred worldwide (140/100,000 inhabitants). For the same year, there was an estimated 11 million prevalent cases $(170 / 100,000$ inhabitants) and a mortality rate of 21/100,000 inhabitants ${ }^{(2)}$.

In Brazil, for the year 2008, the occurrence of 89,000 new cases, an incidence of 46 cases/100,000 inhabitants and a prevalence of 29/100,000 inhabitants was estimated for all forms of $\mathrm{TB}^{(2)}$. The Northeast region, in 2008, ranked second in the percentage of TB cases by region in Brazil, concentrating $28.46 \%$ of cases 
and presenting an mean coefficient of incidence of 35 cases per 100,000 inhabitants ${ }^{(3)}$.

In 2006, the WHO proposed a plan of TB control, which highlighted the importance of the participation and support of the TB patients and of the communities in the fight against the disease. The cited plan integrated issues related to defense of interests, communication, social mobilization and declaration of the rights of patients to tuberculosis care ${ }^{(4)}$.

Recognition of TB control involving community participation is articulated in the debate on health promotion, strengthened in recent decades, based on proposals of healthy cities, of healthy public policies and of intersectorality. Intersectoral action is comprehended as "a recognized relationship between one or more parts of the health sector with one or more parts of another sector, which has been formed to act on an issue, to achieve health outcomes in a more effective, efficient or sustainable way, than could be achieved by the health sector acting alone"(5-6).

The effective existence of intersectoral social policies and of an unrestricted commitment to life and human dignity can be considered as measures capable of reversing the current health indicators, thus contributing to improving the quality of life of the population ${ }^{(5)}$. In Brazil, the National Conference on Health, held in 2001, expressed the need to "implement intersectoral policies for health promotion through the concept of healthy municipalities", guiding the organization of health care through the Family Health Strategy and Community Health Agents Program (PACS).

A recent study designed to evaluate the performance of family health teams (FHTs), in TB control, in a municipality of the metropolitan region of Paraíba State, considering the dimension of the bond, found that despite this city having implemented the Directly Observed Treatment, Short-course (DOTS) and it having been decentralized to all the Family Health Units (FHUs), there are problems that weaken the control of the disease by the local division. Part of the problem lies within the micro-policies of health, which involve the process of work of the teams and the relationship of professionals with TB patients and their communities. The other part is represented by the bond between the team and the other subjects of the care process, i.e. society in general and the managers of public health policies( ${ }^{(7)}$.

A study performed in Sao José do Rio Preto, São Paulo, analyzed the epidemiological situation of TB in relation to the socioeconomic characteristics of the municipality, in the period 1998 to 2004, and confirmed the determination of the disease, in the studied scenario, by the living conditions of the population ${ }^{(8)}$, which strengthens the importance of comprehensive intervention focused on the person, the family and the community. This was also observed in another study, which analyzed the role of the nursing professional in tuberculosis control from the perspective of equity, in the context of the countries of Latin America(9).

Recognizing that TB control requires integrated and permanent action in the field of Primary Health Care $(\mathrm{PHC})$, as well as an improvement in living standards and a reduction in social inequality, considering the guidelines and strategies outlined in the Brazilian National Health System (SUS), this study aimed to analyze the performance of the FHTs in TB control, according to the relationship between the bond and the development of intersectoral actions in a municipality in the metropolitan region of João Pessoa - Paraíba.

\section{Method}

This is a qualitative study conducted in the municipality belonging to the $1^{\text {st }}$ Regional Health Center of the State of Paraiba (BR). The qualitative approach proposes subjectivity as the foundation of meaning, in which social relationships are evidenced as a result of emotional, rational and creative human activity, which can be apprehended through the quotidian, the experience and the explanation of common sense(10). In line with the characteristics of this approach, for the process of empirical analysis, the technique of discourse analysis was chosen, because it is indicated in qualitative research due to the possibilities of relating material that involves values, necessary and preferable judgments as arguments, or as a means capable of revealing the world view and, therefore, the ideological position of the discursive subject(11)

The municipality scenario of the study is enabled in the form of Full Management of Systems since 2003 and has twenty-eight FHTs, which are responsible for the operationalization of the DOTS. It also has two outpatient clinics, a maternity hospital - where the BCG vaccine is given, a Municipal Central Laboratory, responsible for the bacilloscopy diagnosis and control, and five stations for the collection of sputum samples.

The study was conducted between April 24 and May 8, 2007, and the professionals that formed the sixteen teams that were responsible for monitoring the users in treatment for TB in the municipality at that time were invited. Only thirty-seven professionals participated. 
To construct the empirical material the focus group (FG) technique was used, which comprises the collection of data through group interactions while discussing a particular topic suggested by the researcher, occupying, as a technique, an intermediate position between participant observation and in-depth interview ${ }^{(12)}$.

Considering that in the FG technique the groups should be small and homogeneous, not exceeding 12 components per group ${ }^{(13)}$, with the collaboration of two observers, seven focus groups were conducted: two groups with nurses (with seven and six participants in each), two groups with auxiliary nurses and nursing technicians (with six and seven participants in each), a group with CHAs (six participants) and a group with physicians (five participants). The groups were held in the Human Resources Training Center (CEFOR) of the municipality, from $3 \mathrm{pm}$ and lasted an average of one hour and forty minutes. The schedule was previously agreed with the local coordination of the Primary Health Care and Tuberculosis Control Program.

The focus group discussions were guided by a previously prepared script, and the statements of the participants registered by the observers in spreadsheets, prepared by the researchers, and recorded conforming to authorization granted by the participants. As a trigger for discussion three situations involving actions of the FHT in the care to the user with TB were presented, which were preceded by the introduction of the participants, explanation of the research objectives, rationale for use of the recording device, explanation regarding the confidentiality of statements and signing of terms of free prior informed consent.

Categorization of the statements was performed using the technique of discourse analysis ${ }^{(11)}$ and obeyed the following steps: transcription of the statements in full, printing and reading of the texts, identification of the themes related to the object and aims of the study; cutting, decomposition of the texts that present the recurring themes for the different subjects of the research; grouping of the texts that refer to coincident themes, allowing the formation of blocks of meaning, which guide the construction of sub-categories, which in turn, explain the large empirical category identified in this study. The challenges of the family health teams in tuberculosis control considering intersectoral action.

Participants were encoded with letters and numbers to ensure their anonymity as well as to meet the requirements proposed by Resolution 196/96 of the National Health Council, which governs the rules and guidelines on research involving human beings. The project that gave rise to this study was approved by the Research Ethics Committee of the Center of Health Sciences, of the Federal University of Paraíba, on March 28, 2007, under protocol number 936/2007.

\section{Results and Discussion}

\section{Intersectoral action and bonding in tuberculosis control: the challenges for the family health teams}

The statements of the FHT professionals of the municipality confirmed the potential of the Family Health strategy to reorganize the health service from the perspective of the $\mathrm{PHC}$, to the extent that it has the potential to change the care model, especially by facilitating people's access to the health services. Apart from this aspect, the following advances in relation to TB control were highlighted: the presence of a multidisciplinary team, available 40 hours a week, developing actions of prevention, cure, rehabilitation and conducting domicile visits; the early identification of respiratory symptomatic people, the priority of treatment of patients with TB in the FHU, the availability of medication and the offer of bacilloscopy tests. One nursing technician reported: Today he [the TB patient] already gets the medication easier. It's closer, it is convenient. It became easier because once he used to go to the hospital. There were cases where the patients were interned, they spent six months in the hospital. Today, the medication is available within the unit (NT 9).

In this particular situation, there seems to be a recognition of the political commitment of the manager - one of the pillars of the DOTS strategy - as to the guarantee of the specific medication for the treatment of TB, although a paucity of pharmacological options occurs when the person with TB presents side effects to the specific medication or carries other associated diseases, as evidenced in the following statement: You do not have a cough syrup, you do not have an antibiotic to cure an associated pathology, do not have vitamins to give this patient to make him feel better (P 3). The cited problems have hampered the continuity of treatment, and consequently, the control of the disease as stated by the community health agent: Now he just gave up [to treat TB]. Last week I went looking for him again and talked to him. He said to me that really he had a lot of willpower to finish this time. But, just he had a lack of food. So he was in agony every time I gave the medication ( $\mathrm{CHA} 1$ ).

The above statement also denounces the socioeconomically disadvantaged situation that many people who develop TB experience. It has been verified that 
the state of poverty contributes to noncompliance with treatment, which currently constitutes one of the most serious problems related to the control of the disease. The patients have access to medication to treat the disease, but their financial conditions do not favor the acquisition of food. In this case, hunger sharpens the gastric discomfort which often leads the user to abandon the treatment, therefore the care of patients with TB often requires social support activities beyond the directly observed therapy(14). Thus, social support can be considered as one of the essential factors to improve the quality of life, self-esteem and autonomy of these people. The condition for the survival of most patients is reported by the CHA: It's precarious, because what I know is that the tuberculosis patient is entitled to a basic food hamper, of an adequate food intake [...] But, they do not have because everyone there is without a job (CHA 5); He was unable even to buy food, because then, if you make a visit there, you will see that the situation is not good (CHA 4).

Recognizing the situation of poverty of people with $\mathrm{TB}$, the sensitized FHTs adopt strategies to minimize the suffering of these individuals and ensure continuity of treatment, as shown in the following reports: (...) he had no money to come and do the test [...]. And so, we helped him ... and eventually we even gave him the money to do ... [the treatment] (NT 10), Each [professional]... takes some food to encourage them more, because in reality, when we arrive at a patient's home we feel pity... (NT 3); Even the agents who already earn little, don't they? But thank God, the money was enough. The nurses and the physicians gave the bulk. They [the nurses] stayed with us working late making the salad, understand? (CHA 4).

Actions such as these show solidarity on the part of the FHT, but one must consider that such attitudes are focused and do not respond to the broader needs linked to the problem of TB, which also involve the efforts of the $\mathrm{FHT}$ and require the action of multiple actors, through the organization of a network, in which responsibilities are shared in joint actions. Thus, it was verified that some problems related to the disarticulation of these actors can hamper disease control at the local level, as shown in the following statements: how can we do it if they [the managers] do not give any conditions to us? (CHA 4); Unfortunately we have a community that does not want, they are totally disinterested. They are aggressive, totally uninterested (P 4). There is, accordingly, the need to develop policies that make possible intersectoral measures that promote the health and well-being of the people who are, above all, citizens, whose rights are being denied(15).

The importance of including civil society in combating the spread of TB is also considered, as a legitimate resource for the exercise of social control through the participation in health councils in the three spheres of government. Society participation contributes to the definition of health policies that facilitate the promotion of quality of life and the direction of the application of resources. The influence of the Declaration of Amsterdam, in 2000, should be highlighted here, recommending that for the participating countries to control the disease it would be necessary to monitor and evaluate TB control programs and to support partnerships with nongovernmental organizations (NGOs) and with the community. Thus, it is highlighted that the lack of community participation contributes to the slowness of the managers in the release of resources, for the establishment and implementation of policies to control $\mathrm{TB}^{(16)}$.

Another remarkable situation of a social nature that hinders the fight against the spread of TB is the comorbidity with alcoholism. Alcohol dependence emerges as the most important condition of mental health in Brazil, where about $8 \%$ of the adult male population needs some medical care against the harmful use of

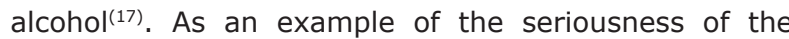
association of TB with alcohol dependence the following report is presented: but then, when he began to feel better, after one month, then he went back to drugs, to alcohol. When I went to visit, he was laying on the sidewalk. The health agent was monitoring every day, was verbally threatened, physically assaulted, I communicated this to the coordinator, all because I did not know what else to do! Actually, I do not know what to do. He abandoned treatment again ( $\mathrm{N} 1$ ).

Considering the current policy of decentralization of TB control actions to the Family Health Strategy and its responsibility in the organization of the line of care of patients with TB, it is emphasized that intersectoral action strengthens the bond - a dimension of the PHC between the family health team, the TB patients, their families and the community, as they potentiate the construction of interpersonal ties and articulate efforts reflected in the mutual cooperation between different sectors for the promotion of health.

In cases of TB associated with the use of alcohol, the FHTs can form partnerships. Among other sectors that can be integrated are the group of Alcoholics Anonymous $(A A)$, the church and the Centers for Psychosocial Care (CAPS), which adopt the approach of mental health care and strategies for welcoming and bonding with people in drug abuse situations. The articulator role of the FHT with the mental health network, as well as other segments 
and sectors of social support has been highlighted as an important strategy for addressing the abandonment of TB treatment, thereby favoring the control of the dissemination of the disease(18).

TB control does not only depend on the action of the FHTs, as one physician said: The responsibility is not just of the team. It is a trio: it is the team, the patient with the family, because if the family is not involved the patient also will not be, and the management (P 3). However, extending this pertinent observation of the health professional, it is important to emphasize that the responsibility for TB control goes beyond the involvement of the actors cited. Reality has shown that the lack of intersectoral policies and the weak participation of society threaten the efficacy of the DOTS strategy and the recommendments of the 2006 Health Pact. Therefore, the inclusion of civil society is insisted on for health teams to develop work strategies with the active participation of patients, families and organized segments of the community in order to include them as actors in TB control(19).

It is considered that TB control is conditioned by the actions related to the fields of micro and macro-policies. In this sense, the existence of two fields for health policies are considered: in one the micro-policies of health are concentrated and in the other their connections, flows and circuits, which is conventionally called the "health system", i.e. the field of macro-policies(20). From the perspective of co-management in health, i.e. the expansion of autonomy and co-responsibility among those involved with health care, subjects in TB control can be considered to be, the person affected by the disease and their families, health workers, other sectors of society and government with their health policies.

Actions considered inherent to the field of macropolicies and necessary for the quality of care to people with TB and therefore beyond the jurisdiction of the FHTs are: the political commitment to providing the FHU with physical and material conditions for its full operation, the organization of the PHC services; articulation with the referral services; and the promotion of training of human resources in the thematic, the strengthening of labor relations and the legitimization of the autonomy of the professional categories that make up the FHTs; the development of intersectoral actions that make the inclusion of the person with TB and community participation viable in this process; the family support of the patient and, finally, the promotion of dignified conditions of life and the valorization of self-care ${ }^{(7)}$.

In the context of TB control actions, the liaison with the education sector is also emphasized, as related to both training the professionals to better deal with the person affected by TB, as well as increasing the potential of the actions of health education, necessary to strengthen social control, from the perspective of PHC.

With regard to training, the professionals involved in the study revealed, for the most part, the difficulty in participating in training related to $T B$, which limits them technically in their development of actions recommended by the Tuberculosis Control Program (TCP): But, I never received the issue of notification from the physician. And I've already talked to her. One of the difficulties that she and other physicians talk about is that it is very difficult to have training for them (N 4); My auxiliary nurse, she never had training (N 1).

It is important to consider the role of the States of the Federation in the technical consultation and in the training of human resources for the municipalities, to improve the performance of the professionals in the fight against TB. The seriousness of the situation is recognized by the physician when she says: So this has severe repercussions in the end [...]. Today I have the responsibility to train these community agents. I think it's the Health Secretariat's responsibility, isn't this right? We have to standardize it! Here it's like this: someone gives an order, the next day there is already another order! (P 2).

Based on the last statements, a need can be verified for greater commitment and investment from the managers in training processes that lead to the transformation of practices and the overcoming of the pandemic that is tuberculosis, through positive changes of epidemiological situations. Although the Ministry of Health (MH) have put in place a national plan that emphasizes human resources training ${ }^{(21)}$, it is recognized that this is still insufficient due to the quantity of professionals who deal with TB, because the opportunities are limited and sporadic as shown in the following report: So we see that there is not much space, for example, you have this training from the State. They provide very few places! So this makes it difficult, because if they had everyone from the municipality it would be good, because everyone would be together, with their experiences. So I think it would be great, but the difficulties are great (N 3).

It is verified that the municipality is still incipient in the policy of training in TB for the FHT professionals, a fact that represents a major threat to the efficacy of the DOTS strategy, and may also alter the epidemiological pattern of disease in the municipality. However, it is noteworthy that only favoring the inclusion of these professionals in the training process, providing more places, will not resolve the problem of $T B$, since the health training has been governed by the Flexnerian 
model, fragmented and focused on biological aspects.

Therefore, it is necessary to establish procedures for the training of health professionals which stimulate humanization based practices, in the welcoming and in the responsibility, targeted at users and health services, as well as for the development of projects of production of autonomy in care and of production of life as learning objects and assembling of the profiles of individual and collective work $^{(22)}$. This means that the training processes, besides considering the specific skills of each professional, should be oriented toward the production of care in a team and based on the concept of permanent health education (PHE), which is supported by the principles and guidelines of the Brazilian National Health System (SUS) and proposed to implement processes with the capacity to impact in education, healthcare management, practices of care and social control in health(23)

With respect to health education actions, the statement show that these actions have not been prioritized in the work process of the FHT: I'll be honest: we do not do training frequently because our routine is very difficult (N 6).

The fact that health education is not prioritized reveals contradictions. The first concerns the failure of one of the activities recommended by the $\mathrm{MH}$ for the actions of the FHTs in TB control(24). The second relates to the issue of health education being implicated in one of the dimensions identified by the PHC to promote the health of people, of the community, i.e. the dimension of community orientation ${ }^{(25)}$. The third contradiction is intrinsically linked to the others, since the lack of health education influences the health needs of individuals, of families and of the community. As an example, a $\mathrm{CHA}$ reported: There where I live, in my area, they give more information, they want to know more about the disease. For them this is important information. Because people are curious to know if they have to be careful too (CHA 6).

Therefore, it is recognized that health education constitutes a fundamental prerequisite for the promotion of care for people with TB, and to combat the stigma associated with this disease, which is strongly present in society. The statement of a nurse validates this need: The user [with TB] of Santa Rita, 27 years of age, came on Monday - eight days ago - with his brother for me to give him something in writing to give to his boss saying he had no serious problem, because the boss would not sign his work papers. He works in a supermarket. So, his colleagues were afraid to go near him and he wanted something like that, that I give him something in writing for the people to believe that the disease does not prevented him from working, of having contact with colleagues, being together with people, understand? (N 2).

To include, in a broad way, the participation of civil society in the control of TB, a disease in which the care of people that are carriers includes the aspects of interdisciplinarity, aims for the meanings and significance of otherness and of solidarity to be materialized in the respect for the lives of these people. Thus, it is possible to sensitize civil society to comprehend that social control in the Brazilian health system, means the right and duty of society to participate in debate and decision regarding the formulation, implementation and evaluation of the national health policy ${ }^{(23)}$.

\section{Conclusion}

Among the problems revealed, that negatively impact on TB control in the municipality, there were: the lack of actions aimed at promoting intersectoral action, the small amount of community participation in combating the disease, the lack of professionals technically qualified in relation to the issue of TB and the unfavorable social condition of most people with the disease.

The results elucidated the contradictions and inconsistencies between the practice of the FHT and the official discourse of health policies, however, the study highlights the potential of the Family Health Strategy to organize actions of TB prevention, control, diagnosis and treatment according to the reference of the PHC. From the perspective of a broader concept of health and considering integral care, it can be said that the lack of intersectoral action to combat TB weakens the production of a bond between patients and the FHTs, because it interferes in the resolvability of the needs demanded by these individuals and in the credibility of the team responsible for care, given that the issue requires effective assistance.

In summary, it is necessary to adopt intersectoral measures guided by the principles of the SUS, as well as the articulation of knowledge, power and diverse interests, to address complex problems such as TB, prioritizing above all, actions that the promote the organization of the services, having the PHC as the theoretical structuring axis, and the training of human resources in the perspective of co-management and increased autonomy of the individuals involved in the care.

The study also revealed that despite the technical limitations of some professionals, the precariousness of the working process in the $\mathrm{FHU}$, the insufficiency of 
financial resources and the inadequacies of the physical structure of the FHU to promote actions together with the community, there is the effort and commitment of the FHTs in the successful treatment of people affected by $T B$, by establishing bonds with patients. Thus, it is believed that the implementation of intersectoral measures and the encouragement of co-management and user autonomy, linked to the efforts of the FHT to establish relationships with the patients and their families, promoting the integral care of patients with TB within the scope of PHC.

\section{References}

1. Kristski AL, Villa TCS, Trajman A, Lapa e Silva JR, Medronho RA, Ruffino-Netto A. Duas décadas de pesquisa em tuberculose no Brasil: estado da arte das publicações científicas. Rev Saúde Pública. 2008;41(1):9-14.

2. World Health Organization. Global tuberculosis control: a short update to the 2009 report. Geneva: WHO; 2010 [acesso 11 jun 2010]. Disponível em: http://www. who.int/tb/publications/global_report/2009/update/en/ index.html

3. Barreira D. Programa Nacional de Controle da Tuberculose - PNCT. Secretaria de Vigilância em Saúde. Brasília: MS; 2009 [acesso 20 out 2009]. Disponível em: www.cve.saude.sp.gov.br/htm/tb/eventos/ forum/04TB09_Brasil_DBarreira.pdf

4. World Health Organization [internet]. A Estratégia Stop TB. 2006. [acesso 05 março 2008]. Disponível em: http://www.who.int/tb/publications/2006/stoptb_ strategy_por.pdf.

5. Westphal MF. O movimento cidades/municípios saudáveis: um compromisso com a qualidade de vida. Rev Ciênc Saúde Colet. 2000;5(1):39-51.

6. Rede Unida [internet]. 2007 [acesso 10 jun 2007]. Disponível em: http://www.redeunida.org.br

7. Gomes ALC, Sá LD. As concepções de vínculo e a relação com o controle da tuberculose. Rev Esc Enferm USP. 2009;43(2):365-72.

8. Santos MLSG, Vendramini SHF, Gazetta CE, Oliveira SAC, Villa TCS. Pobreza: caracterização socioeconômica da tuberculose. Rev. Latino-Am. Enfermagem [serial on the online]. 2007;15(spe):762-7. doi: 10.1590/S010411692007000700008.

9. Oblitas FYM, Loncharich N, Salazar ME, David HML, Silva IVD. Nursings role in tuberculosis control: a discussion from the perspective of equity. Rev. Latino-Am. Enfermagem [serial on the Internet]. 2010;18(1):130-8. doi: 10.1590/S0104-11692010000100020.
10. Minayo MCS. O desafio do conhecimento. 7a ed. São Paulo: Hucitec-Abrasco; 2000.

11. Fiorin JL. Elementos da análise de discurso. 7a ed. São Paulo: Contexto-Edusp; 1999.

12. Morgan DL. Focus group as qualitative research. 2 . ed. California: Sage Publications; 1997.

13. Cruz O Neto, Moreira MR, Sucena LFM. Grupos focais e pesquisa social: o debate orientado como técnica de investigação. Rio de Janeiro: Fiocruz; 2005.

14. Gonzáles RIC, Monroe AA, Arcêncio RA, Oliveira MF, Ruffino-Netto A, Villa TCS. Indicadores de desempenho do DOT no domicílio para o controle da tuberculose em município de grande porte, SP, Brasil. Rev. Latino-Am. Enfermagem [periódico na internet]. 2008; 16(1): 95100. doi: 10.1590/S0104-11692008000100015.

15. Sá LD, Nogueira JA, Silveira RMG, Villa TCS, Gomes ALC, Nobrega RG, Ruffino Netto A. Humanização do cuidado no SUS e os direitos dos doentes de tuberculose. In: Villa TCS, Rufino Netto A. Tuberculose: pesquisas operacionais. Ribeirão Preto (SP): FUNPEC Editora; 2009.

16. Santos-Filho ET, Gomes ZMS. Estratégias de controle da tuberculose no Brasil: articulação e participação da sociedade civil. Rev Saúde Pública. 2007;41(Supl 1):111-6.

17. Zago MA. A pesquisa clinica no Brasil. Ciênc Saúde Colet. 2004;9(2):353-74.

18. Sá LD, Souza KMJ, Nunes MG, Palha PF, Nogueira JA, Villa TCS. Tratamento da tuberculose em unidades de saúde da família: histórias de abandono. Texto Contexto Enferm. [periódico na internet]. 2007;16(4):712-8. doi: 10.1590/S0104-07072007000400016.

19. Oliveira SAC, Ruffino Netto A, Villa TC, Vendramini SHF, Andrade RL de P, Scatena LM, et al. Serviços de saúde no controle da tuberculose: enfoque na família e orientação para a comunidade. Rev. LatinoAm. Enfermagem [periódico na internet]. 2009 [acesso 01 out 2009]; 17(3):361-7. Disponível em: http://www.scielo.br/scielo.php?pid=S0104$11692009000300013 \&$ script $=s c i \_$arttext\&tIng $=p t$

20. Cecílio LCO. As necessidades de saúde como conceito estruturante na luta pela integralidade e equidade na atenção à saúde. In: Pinheiro R, Mattos RA. Os sentidos da integralidade na atenção e no cuidado à saúde. Rio de Janeiro: IMS/ABRASCO; 2006.

21. Santos J. Resposta brasileira ao controle da tuberculose. Rev Saúde Pública. 2007;41(1):89-94.

22. Franco TB. Produção do cuidado e produção pedagógica: integração de cenários do sistema de saúde no Brasil. Interface - Comunic Saúde Educ. 
2007;11(23):427-38.

23. Ceccim RB, Feuerwerker LCM. O quadrilátero da formação para a área da saúde: Physis: Rev Saúde Colet. 2004;14(1):41-65.

24. Ministério da Saúde (BR) Manual técnico para o controle de tuberculose. Brasília (DF): Ministério da Saúde; 2002.

25. Starfield B. Atenção primária: equilíbrio entre necessidades de saúde, serviços e tecnologia. Brasília: UNESCO; 2002. 